\title{
Influence of Streptozotocin- and Alloxan-Induced Diabetes in the Rat on Collagenase and Certain Lysosomal Enzymes in Relation to the Degradation of Connective Tissue Proteins
}

\author{
S. Mohanam and S. M. Bose \\ Biochemistry Laboratory, Central Leather Research Institute, Adyar, Madras, India
}

\begin{abstract}
Summary. The activity of collagenase and certain lysosomal hydrolases (cathepsin $\mathrm{B}_{1}$, cathepsin $\mathrm{D}, \beta$-glucuronidase and $\beta$ $\mathrm{N}$-acetyl glucosaminidase) was studied in serum and tissues of rats with streptozotocin- or alloxan-induced diabetes. The activity of serum lysosomal enzymes was increased in both groups $(p<0.05)$. Both streptozotocin- and alloxan-diabetic animals showed significantly higher dermal collagenase activity than those of controls $(p<0.01)$, but the liver and spleen showed similar activities; there was a significant decrease in the renal collagenase activity of streptozotocin-diabetic rats $(p<0.05)$. Comparison of the alloxan- or streptozotocin-treated groups with control animals showed an increase in lysosomal enzymes (cathepsin $B_{1}$, cathepsin $D, \beta$-glucuronidase
\end{abstract}

and $\beta$-N-acetyl glucosaminidase in skin, liver and spleen) $(p<0.05)$ but $\beta$-N-acetyl glucosaminidase was unchanged in the spleen of streptozotocin-diabetic rats. There was no difference in renal cathepsin $B_{1}$ and $D$ in control versus alloxandiabetic rats, but there was an increase in $\beta$-glucuronidase and $\beta$-N-acetyl glucosaminidase $(p<0.05)$. The streptozotocindiabetic animals showed decreased activities of renal lysosomal enzymes $(p<0.05)$, but similar activity of cathepsin D to the control animals.

Key words: Diabetes, rat, collagenase, cathepsin $\mathrm{B}_{1}$, cathepsin $\mathrm{D}, \beta$-glucuronidase, $\beta$ - $\mathrm{N}$-acetyl glucosaminidase, lysosomal hydrolases, connective tissue, streptozotocin, alloxan.
Activities of the plasma or serum lysosomal enzymes such as $\beta$-glucuronidase and $\beta$ - $\mathrm{N}$-acetyl glucosaminidase have been shown to be elevated in diabetic patients [4, 23] and in various animal models including chemically induced diabetes in rats [35] and Chinese hamsters [7]. The activity of collagenolytic enzyme capable of solubilising collagen is also increased in the gingiva of animals rendered diabetic by alloxan [29]. Changes in the activities of lysosomal hydrolases involved in the degradation of connective tissue proteins such as, proteoglycans [20], glycoproteins [21] and collagen [8] may play important roles in the pathophysiology of the diabetic sequelae. Studies have therefore been initiated on the levels of collagenase and of other lysosomal enzymes (cathepsin $\mathrm{B}_{1}$, cathepsin D, $\beta$-glucuronidase and $\beta$-N-acetyl glucosaminidase) in serum and tissues of animals with two types of experimentally induced diabetes.

\section{Materials and Methods}

Four-month-old male albino rats were divided into three groups: control animals, streptozotocin-treated and alloxan-treated. Rats were starved for $24 \mathrm{~h}$ and given an IP injection of alloxan in $0.154 \mathrm{~mol} / 1$
$\mathrm{NaCl}(20 \mathrm{mg} / 100 \mathrm{~g}$ body weight) or an IV injection of streptozotocin (Upjohn, Kalamazoo, Michigan, USA) in isotonic saline containing $1 \mathrm{~mol} / 1$ citric acid (pH 4.5$)(6.5 \mathrm{mg} / 100 \mathrm{~g}$ body weight) [24]. All animals received commercial rat feed (Hindustan Lever, Bombay) and water ad libitum. Body weights were recorded at weekly intervals. Blood samples were taken weekly from the tails of fasted rats for measurement of glucose [24]. At the end of the experimental period ( 3 weeks), 12 rats in each group were killed by decapitation and the skin, liver, kidney and spleen were removed immediately in ice-cold containers and stored at $-20^{\circ} \mathrm{C}$. Blood was collected by heart puncture before killing the rats and allowed to clot after standing at room temperature for 2-4h. The serum was separated by centrifugation at low speed and stored at $-20^{\circ} \mathrm{C}$ until assayed. For the convenience of analysis, tissues or blood from two rats were pooled together to make one sample thus making six samples in each group. Tissue samples were analysed for collagenase, cathepsin $\mathrm{B}_{1}$, cathepsin $\mathrm{D}, \beta$-glucuronidase and $\beta$-N-acetyl glucosaminidase activities and serum was analysed for these enzymes except collagenase.

\section{Preparation of Enzyme Extract from Tissues}

The skins were shaved and sliced approximately $5-10 \mu$ with a microtome at $0^{\circ} \mathrm{C}$. The enzyme extract was prepared by homogenising the weighed tissue samples separately in a Potter Elvenhjem type homogenizer (Remi, Bombay, India) using ice-cold $0.25 \mathrm{~mol} / 1$ sucrose solution. Conditions of homogenization were standardised for speed and time of homogenization and the volumes of medium used were identical in all cases. The homogenates were then centrifuged for $10 \mathrm{~min}$ at $600 \mathrm{~g}$. The residue containing nuclei, unbroken cells and plasma 
Table 1. Effect of streptozotocin- and alloxan-induced diabetes on the serum activities of cathepsin $\mathrm{B}_{1}$, cathepsin $\mathrm{D}, \beta$-D-glucuronidase and $\beta$-N-acetyl glucosaminidase

\begin{tabular}{|c|c|c|c|}
\hline Enzyme & $\begin{array}{l}\text { Control } \\
\text { rats }\end{array}$ & $\begin{array}{l}\text { Strepto- } \\
\text { zotocin }\end{array}$ & Alloxan \\
\hline $\begin{array}{l}\text { Cathepsin } B_{1} \\
\left(\mu \mathrm{m} \text { p-nitroaniline } \cdot \mathrm{h}^{-1} \text {. }\right. \\
\left.100 \mathrm{mg} \text { protein }{ }^{-1}\right)\end{array}$ & $15.4 \pm 0.5$ & $17.4 \pm 0.6^{\mathrm{a}}$ & $18.6 \pm 0.6^{\mathrm{a}}$ \\
\hline $\begin{array}{l}\text { Cathepsin D } \\
\left(\mu \mathrm{m} \text { tyrosine } \cdot \mathrm{h}^{-1}\right. \\
100 \mathrm{mg} \text { protein } \\
-1)\end{array}$ & $10.4 \pm 0.3$ & $12.1 \pm 0.4^{b}$ & $11.8 \pm 0.4^{\mathrm{a}}$ \\
\hline $\begin{array}{l}\beta \text {-glucuronidase } \\
\quad\left(\mu \mathrm{m} \text { p-nitrophenol } \cdot \mathrm{h}^{-1}\right. \\
100 \mathrm{mg} \text { protein }\end{array}$ & $2.6 \pm 0.1$ & $3.2 \pm 0.1^{\mathrm{b}}$ & $3.1 \pm 0.1^{\mathrm{b}}$ \\
\hline $\begin{array}{l}\beta \text {-N-acetyl glucosaminidase } \\
\left(\mu \mathrm{m} \text { p-nitrophenol } \cdot \mathrm{h}^{-1}\right. \\
100 \mathrm{mg} \text { protein } \\
\end{array}$ & $2.8 \pm 0.1$ & $3.6 \pm 0.1^{\mathrm{b}}$ & $3.5 \pm 0.1^{b}$ \\
\hline
\end{tabular}

Results expressed as mean $\pm \mathrm{SEM}$; six samples with two animals sera in each sample a $p<0.05 ;$ b $p<0.01$

membrane were discarded and the supernatant was again centrifuged at $16,000 \mathrm{~g}$ for $30 \mathrm{~min}$ at $4^{\circ} \mathrm{C}$. The supernatants were used as the source of free activities of lysosomal hydrolases [28] and enzyme activities were estimated in presence of $0.2 \%(\mathrm{w} / \mathrm{v})$ Triton X 100 .

For collagenase, the weighed tissue samples were homogenised separately in a Teflon glass homogeniser using ice-cold $0.5 \mathrm{~mol} / \mathrm{1}$ Tris$\mathrm{HCl}$ buffer $(\mathrm{pH} 7.8)$ containing $\mathrm{NaCl}(0.2 \mathrm{~mol} / \mathrm{l})$ and $\mathrm{CaCl}_{2}$ $(5 \mathrm{mmol} / \mathrm{l})$ and the extract was frozen and thawed three times and centrifuged at $16,000 \mathrm{~g}$ for $30 \mathrm{~min}$. The supernatant containing $0.5-1.5 \mathrm{mg}$ protein $/ \mathrm{ml}$ was used for collagenase assay.

\section{Preparation of Substrate for Collagenase}

Twenty-five-day-old guinea pigs, weighing 225-250g, were injected IP with $200 \mu \mathrm{Ci}$ of ${ }^{14} \mathrm{C}$ glycine (Bhabha Atomic Research Centre, Bombay) in sterile $0.154 \mathrm{~mol} / 1 \mathrm{NaCl}$. Six hours later the animals were anaesthetized with ether and killed by decapitation. The skins were shaved, minced with $\mathrm{NaCl}(0.5 \mathrm{~mol} / \mathrm{l})$ in the cold and the neutral salt soluble collagen was extracted and purified as described previously [25]. The collagen preparations were freeze-dried and stored at $-20^{\circ} \mathrm{C}$ until use. The specific radioactivity was found to be in the range of $2500 \mathrm{cpm} / \mathrm{mg}$ of collagen and the purity of the collagen was confirmed by disc electrophoresis in 5\% polyacrylamide gels containing sodium dodecyl sulphate [25].

\section{Collagenase Assay}

The activity of collagenase was assayed as described by Terato et al. [34]. For enzyme assay, $0.1 \mathrm{ml}$ of $0.4 \%(\mathrm{w} / \mathrm{v})$ labelled collagen dissolved in acetic acid $(5 \mathrm{mmol} / \mathrm{l}), 0.1 \mathrm{ml}$ of $0.1 \mathrm{~mol} / \mathrm{l}$ Tris- $\mathrm{HCl}$ buffer ( $\mathrm{pH} 7.8)$ containing $\mathrm{NaCl}(0.4 \mathrm{~mol} / \mathrm{l}) \mathrm{CaCl}_{2}(10 \mathrm{mmol} / \mathrm{l})$ and glucose $(1 \mathrm{~mol} / \mathrm{l})$ and $0.2 \mathrm{ml}$ of enzyme solution to be tested were mixed and incubated for $4 \mathrm{~h}$ at $35^{\circ} \mathrm{C}$ (a temperature between the denaturation temperature of the native collagen and its enzyme digests). The enzymic reaction was stopped by adding $20 \mu 1$ of o-phenanthroline $(80 \mathrm{mmol} / 1)$ dissolved in $50 \%$ dioxane and the reaction products were extracted by vigorous shaking after the addition of $0.4 \mathrm{ml}$ of dioxane and centrifuged at $6000 \mathrm{rev} / \mathrm{min}$ for $20 \mathrm{~min}$ to precipitate the residual undigested collagen. The supernatant $(0.5 \mathrm{ml})$ was added to $10 \mathrm{ml}$ of Brays solution (Nuclear Enterprises, Edinburgh, Scotland, UK) and assayed for ${ }^{14} \mathrm{C}$ radioactivity in an automatic liquid scintillation system LSS 34 (Electronics Corporation of India, Hyderabad). To check the interference by denatured collagen, control assays containing $25 \mu \mathrm{g}$ of trypsin $(2 \times$ crystalline) were performed with each series of assays. After subtracting water and trypsin blank, the results were expressed as $\mathrm{cpm} / \mathrm{mg}$ protein. To verify that the enzyme assayed was a true collagenase, collagen and its degradation products were examined by disc gel electrophoresis.

Cathepsin $B_{1}$ activity was measured by the method of Barret [3] using $\mathrm{N}$ - $\alpha$-benzoyl-DL-arginine p-nitroanilide HCl (BAPA) as substrate. Cathepsin D assay was carried out using $1.5 \%$ haemoglobin as substrate and estimating tyrosine liberated by the method of Sapolsky et al. [31]. $\beta$-glucuronidase activity was measured by the method of Kawai and Anno using p-nitrophenyl $\beta$-D-glucuronide as the substrate [18]. $\beta$-N-acetyl glucosaminidase was assayed as described by Rosenbilt et al. [30] using p-nitrophenyl $\mathrm{N}$-acetyl $\beta$-D-glucosaminide as substrate. Protein content was determined by the method of Lowry et al. [19] using bovine serum albumin as a standard.

\section{Statistical Methods}

The results evaluated using the Student's t-test are expressed as mean \pm SEM. The differences were regarded as significant at the level $p<0.05$.

\section{Results}

Streptozotocin- and alloxan-treated animals lost weight during the experimental period. The fasting blood glucose was raised in all experimental rats (control: $5.3 \pm$ 0.4 ; streptozotocin-diabetic: $22.1 \pm 0.9$ and alloxan-diabetic: $16.4 \pm 0.8 \mathrm{mmol} / 1$ respectively).

The activities of serum cathepsin $\mathrm{B}_{1}$, cathepsin $\mathrm{D}, \beta$ glucuronidase and $\beta$ - $\mathrm{N}$-acetyl $\beta$-glucosaminidase were increased significantly in both streptozotocin- and alloxan-induced diabetic animals compared with controls (Table 1).

The activity of free collagenase increased significantly in the skins of both diabetic groups. However the activity was reduced in the kidney of streptozotocindiabetic rats while in the liver and spleen no significant changes of collagenase were observed. The activity was not altered in liver, kidney and spleen of the alloxandiabetic group. The mode of cleavage of collagen by the collagenase from tissue homogenates of diabetic rats was characterized by disc electrophoresis on sodium dodecyl sulphate polyacrylamide gels. The gel electrophoretic patterns indicated well characterized $\mathrm{TC}_{\mathrm{A}}$ and $\mathrm{TC}_{\mathrm{B}}$ fragments (three-fourth and one-fourth of the intact collagen molecule respectively) supporting that the enzyme assayed was collagenase.

Significant increase in the activity of cathepsin $B_{1}$ was observed in skin, liver and spleen of both types of diabetes. The kidneys of streptozotocin-diabetic rats showed lower enzyme activity whereas alloxan diabetic animals had similar activity as those in the non-diabetic animals (Table 2).

Diabetes rendered by streptozotocin and alloxan caused significant elevation in the cathepsin D activity in the skin, liver and spleen. No difference in renal cathepsin D activity was detected between control and alloxan- or streptozotocin-induced diabetic rats (Table 2).

The levels of $\beta$-glucuronidase in both type of experimentally induced diabetes exceeded those in controls in 
Table 2. Effect of streptozotocin- and alloxan-induced diabetes on the activities of collagenase, cathepsin $\mathrm{B}_{1}$, cathepsin $\mathrm{D}, \beta$-glucuronidase and $\beta$-N-acetyl glucosaminidase in skin, liver, kidney and spleen

\begin{tabular}{|c|c|c|c|c|c|}
\hline Enzyme & Group & Skin & Liver & Kidney & Spleen \\
\hline $\begin{array}{l}\text { Collagenase } \\
\text { (cpm/mg protein) }\end{array}$ & $\begin{array}{l}\text { Control } \\
\text { Streptozotocin } \\
\text { Alloxan }\end{array}$ & $\begin{array}{l}566 \pm 12 \\
738 \pm 15^{b} \\
694 \pm 14^{b}\end{array}$ & $\begin{array}{l}121 \pm 5 \\
138 \pm 8 \\
130 \pm 6\end{array}$ & $\begin{array}{ll}147 & \pm 5 \\
104 & \pm 4^{b} \\
136 & \pm 4\end{array}$ & $\begin{array}{l}138 \pm 6 \\
149 \pm 5 \\
156 \pm 8\end{array}$ \\
\hline $\begin{array}{l}\text { Cathepsin } B_{1} \\
\left(\mu \mathrm{m} \text {-nitroaniline } \mathrm{h}^{-1} \cdot 100 \mathrm{mg}\right. \\
\left.\text { protein }^{-1}\right)\end{array}$ & $\begin{array}{l}\text { Control } \\
\text { Streptozotocin } \\
\text { Alloxan }\end{array}$ & $\begin{array}{l}51.9 \pm 2.8 \\
65.8 \pm 5.3^{\mathrm{a}} \\
61.2 \pm 3.1^{\mathrm{a}}\end{array}$ & $\begin{array}{l}21.5 \pm 1.7 \\
28.7 \pm 1.4^{\mathrm{a}} \\
29.0 \pm 3.1^{\mathrm{a}}\end{array}$ & $\begin{array}{l}32.4 \pm 2.2 \\
26.3 \pm 1.2^{\mathrm{a}} \\
30.3 \pm 3.2\end{array}$ & $\begin{array}{l}40.4 \pm 2.7 \\
52.1 \pm 3.4^{\mathrm{a}} \\
56.5 \pm 4.1^{\mathrm{a}}\end{array}$ \\
\hline $\begin{array}{l}\text { Cathepsin D } \\
\left(\mu \mathrm{m} \text { tyrosine } \cdot \mathrm{h}^{-1} \cdot 100 \mathrm{mg}\right. \\
\left.\text { protein }{ }^{-1}\right)\end{array}$ & $\begin{array}{l}\text { Control } \\
\text { Streptozotocin } \\
\text { Alloxan }\end{array}$ & $\begin{array}{l}36.1 \pm 3.2 \\
50.6 \pm 4.8^{\mathrm{a}} \\
44.2 \pm 2.1^{\mathrm{a}}\end{array}$ & $\begin{array}{l}24.3 \pm 1.1 \\
32.9 \pm 1.7^{\mathrm{b}} \\
31.4 \pm 2.1^{\mathrm{a}}\end{array}$ & $\begin{array}{l}35.6 \pm 2.0 \\
31.1 \pm 2.4 \\
38.8 \pm 2.6\end{array}$ & $\begin{array}{l}28.6 \pm 1.4 \\
35.5 \pm 2.5^{\mathrm{a}} \\
39.6 \pm 2.7^{\mathrm{b}}\end{array}$ \\
\hline $\begin{array}{l}\beta \text {-glucuronidase } \\
\quad\left(\mu \mathrm{m} \text { p-nitrophenol } \cdot \mathrm{h}^{-1}\right. \\
100 \mathrm{mg} \text { protein }\end{array}$ & $\begin{array}{l}\text { Control } \\
\text { Streptozotocin } \\
\text { Alloxan }\end{array}$ & $\begin{array}{l}25.1 \pm 1.7 \\
31.5 \pm 2.0^{\mathrm{a}} \\
36.4 \pm 2.4^{\mathrm{b}}\end{array}$ & $\begin{array}{l}37.6 \pm 2.2 \\
46.1 \pm 2.8^{\mathrm{a}} \\
44.4 \pm 2.2^{\mathrm{a}}\end{array}$ & $\begin{array}{l}26.2 \pm 1.1 \\
20.3 \pm 1.2^{\mathrm{b}} \\
30.6 \pm 1.3^{\mathrm{a}}\end{array}$ & $\begin{array}{l}62.6 \pm 3.6 \\
78.9 \pm 5.4^{\mathrm{a}} \\
80.4 \pm 3.2^{\mathrm{b}}\end{array}$ \\
\hline $\begin{array}{l}\beta \text {-N-acetyl glucosaminidase } \\
\left(\mu \mathrm{m} \text { p-nitrophenol } \cdot \mathrm{h}^{-1} \cdot 100 \mathrm{mg}\right. \\
\left.\text { protein }^{-1}\right)\end{array}$ & $\begin{array}{l}\text { Control } \\
\text { Streptozotocin } \\
\text { Alloxan }\end{array}$ & $\begin{array}{l}52.1 \pm 3.7 \\
68.4 \pm 2.9^{\mathrm{b}} \\
64.5 \pm 4.5^{\mathrm{a}}\end{array}$ & $\begin{array}{l}31.7 \pm 2.5 \\
41.2 \pm 2.3^{\mathrm{a}} \\
43.0 \pm 2.1^{\mathrm{b}}\end{array}$ & $\begin{array}{l}162.5 \pm 7.1 \\
118.3 \pm 6.2^{\mathrm{b}} \\
183.7 \pm 6.7^{\mathrm{a}}\end{array}$ & $\begin{array}{l}43.8 \pm 3.2 \\
37.5 \pm 2.6 \\
54.2 \pm 2.7^{\mathrm{a}}\end{array}$ \\
\hline
\end{tabular}

Results expressed as mean \pm SEM; six samples with two animal tissues in each sample $\quad{ }^{a} p<0.05 ; \quad$ b $p<0.01$.

all the tissues with the exception of kidney of streptozotocin-diabetic rats which showed a decrease (Table 2).

Administration of streptozotocin caused a decrease in the activity of $\beta$-N-acetyl glucosaminidase in the kidney, an increase in the skin and liver but no alteration in the spleen. The activity of this enzyme increased significantly in all the tissues of alloxan-diabetic rats (Table 2).

\section{Discussion}

Diabetes-related changes in the activities of plasma or serum $\beta$-glucuronidase and $\beta$ - $\mathrm{N}$-acetyl glucosaminidase involved in the degradation of glycosaminoglycans and glycoproteins have been reported in diabetic patients [4, $23]$ and in experimentally-induced $[14,35]$ or spontaneously-occurring diabetes [7]. However, no information is available on the changes in collagenase and collagenolytic enzymes, namely cathepsin $B_{1}$ and $D$ involved in collagen degradation in diabetic subjects. The present study has shown an elevation of serum lysosomal enzymes (cathepsin $\mathrm{B}_{1}$, cathepsin $\mathrm{D}, \beta$-glucuronidase and $\beta$-N-acetyl glucosaminidase) in both streptozotocin- and alloxan-treated rats. The increase in the serum lysosomal enzyme activities in diabetes is thought to be caused by release of these enzymes into serum from tissue lysosomes. The liver perfusion experiments reported by Tulsiani et al. [35] suggest that the liver is contributing to the elevated lysosomal hydrolase levels observed in streptozotocin-treated rats. However Chang [6] and Tarui et al. [33] believe that the increased activities of lysosomal enzymes observed in diabetic rats was a result of a decrease in their renal activities. Better control of diabetes with insulin was associated with normalization of the enzyme activities of the serum in the diabetic state suggesting that a chronic deficiency of in- sulin may be related to increased serum lysosomal hydrolase activities. However, streptozotocin-induced and genetically diabetic $d b / d b$ mice [35] showed lower instead of higher activity of plasma lysosomal hydrolases than the non-diabetic mice. The cause for this discrepancy could arise from difference in species or between chemically-induced and hereditary diabetes. Genetic factors also appeared to dictate the diabetes related changes in plasma lysosomal hydrolase activities. From mixing studies between normal and diabetic sera or tissue homogenates no evidence was obtained for the presence of inhibitors or activators of $\beta$-hexosaminidase in diabetic rats $[1,38]$.

The present investigation shows an active collagenolytic enzyme in vivo in the tissue homogenates of normal and diabetic rats. Golub et al. [15] observed that both alloxan- and streptozotocin-induced diabetes stimulated the collagenolytic activity in gingiva in tissue culture. In addition, the diabetic rats exhibited increased urinary excretion of hydroxyproline [24]. The pathophysiological role of the inhibition of collagenolytic systems in the kidney of streptozotocin-diabetic rats is unknown.

The rapid breakdown of collagen in diabetes may not result directly from collagenase activity but may be caused by other collagenolytic enzymes $[5,10,27]$. The initial breakdown of the proteoglycans by these lysosomal enzymes may open up to collagen fibres for attack by collagenase [37]. These lysosomal enzymes may also contribute to the further degradation of collagen fragments produced by the action of collagenase. The destruction of cartilage in experimental diabetes is reported due to the enzymatic degradation of proteoglycans by lysosomal enzymes [32]. Cathepsin $\mathrm{B}_{1}$ [12] has been found to depolymerize collagen fibres [11] and it can further digest collagen to small fragments [5]. In ad- 
dition cathepsin $B_{1}$ [26] and cathepsin $D$ [2] have also been shown to digest the protein moiety of proteoglycans [2] while $\beta$-glucuronidase can digest the polysaccharide moiety suggesting that the connective tissue proteins could be digested by lysosomal hydrolases.

Diabetes induced by alloxan and streptozotocin show some differences. While the activity of lysosomal hydrolases increased or unaltered in the kidney of alloxan-diabetic rats, these enzyme activities have been decreased in streptozotocin-induced diabetes. Comparisons of different metabolic alterations produced by these two diabetogenic agents that might illuminate this question are few in number and their results are conflicting $[17,22,36]$.

Decreased lysosomal enzyme activity in renal tissue of streptozotocin-diabetic rats [14] mice [13] and Chinese hamsters with spontaneous diabetes [6] shows that lysosomal enzyme deficiency could be involved in the genesis of renal microangiopathy. Depression of renal $\beta$-glucuronidase [14] and $\alpha$-mannosidase was observed in streptozotocin-diabetic rats and mice [35] but not in hereditary diabetic $d b / d b$ mice [35]. These conflicting results suggest that diabetic related changes in renal lysosomal hydrolase levels are not regulated by hyperglycaemia alone.

Although renal lysosomal enzymes are decreased in experimental diabetes there is evidence that synthetic enzymes such as lysyl hydroxylase [9] and uridine diphosphate glucose-galactosyl-hydroxylysine transferase [16] exhibit increased activities in diabetic kidneys. Differences in the effects of diabetes on these two classes of enzymes could contribute to the accumulation of connective tissue proteins which in turn have been implicated in the development of diabetic microangiopathy. The changes in these lysosomal enzymes may also reflect biochemical adjustments to the increased deposition of macromolecules in tissues.

Acknowledgements. Our thanks are due to Professor M. Santappa for his keen interest and permission to publish this work. The streptozotocin was obtained through the courtesy of Dr. W.E. Dulin, Upjohn, Kalamazoo, Michigan, USA. S. M. was supported by the Council of Scientific and Industrial Research, New Delhi.

\section{References}

1. Alhadeff JA, Holzinger RT (1982) Characterization of $\beta$-hexosaminidase from liver and sera of diabetic patients and controls. Biochem Medicine 27: 214-225

2. Barrett AJ (1971) Purification and properties of cathepsin D from liver of chicken, rabbit and man. In: Barrett AJ, Dingle JT (eds) Tissue proteinases, North Holland, Amsterdam, pp 109-133

3. Barrett AJ (1972) A new assay for cathepsin $B_{1}$ and other thiol proteinases. Anal Biochem 47: 280-293

4. Bomback FM, Nakagawa S, Kumin S, Nitowsky HM (1976) Altered lysosomal glycohydrolase activities in juvenile diabetes mellitus. Diabetes 25:420-427

5. Burleigh MC, Barrett AJ, Lazarus GS (1974) Cathepsin $B_{1}$, a lysosomal enzyme that degrades native collagen. Biochem $J$ 137: $387-398$
6. Chang AY (1978) Acid glycohydrolase in Chinese hamster with spontaneous diabetes. I. Depressed levels of renal $\alpha$-galactosidase and $\beta$-galactosidase. Biochim Biophys Acta 522: 491-502

7. Chang AY, Perry CS (1978) Acid glycohydrolase in Chinese hamster with spontaneous diabetes. IV Diabetes- and line-dependent variation in plasma enzyme activity. Diabetologia 15: 423-429

8. Coffey JW, Fiedler-Nagy C, Georgiadis AG, Salvador RA (1976) Digestion of native collagen, denatured collagen and collagen fragments by extracts of rat liver lysosomes. J Biol Chem 251: $5280-5282$

9. Cohen MP, Khalifa A (1977) Effect of diabetes and insulin on rat renal glomerular protocollagen hydroxylase activities. Biochim Biophys Acta 496: 88-94

10. Etherington DJ (1972) The nature of the collagenolytic cathepsin of rat liver and its distribution in other rat tissues. Biochem $\mathbf{J} 127$ : $685-692$

11. Etherington DJ (1977) The dissolution of insoluble bovine collagens by cathepsin $B_{1}$ collagenolytic cathepsin and pepsin, the influence of collagen type age and chemical purity on susceptibility. Connect Tissue Res 5: 135-145

12. Evans P, Etherington DJ (1978) Characterisation of cathepsin B and collagenolytic cathepsin from human placenta. Eur J Biochem 83: 87-97

13. Fushimi H, Shibata M, Tarui S (1980) Glycosidase activities in the liver and kidney of hereditary diabetic mice. J Biochem (Tokyo) 87: $941-949$

14. Fushimi H, Tarui $\mathrm{S}$ (1976) $\beta$-glycosidases and diabetic microangiopathy. I Decrease of $\beta$-glycosidase activities in diabetic rat kidney. J Biochem (Tokyo) 79:265-270

15. Golub LM, Schneir M, Ramamurthy NS (1978) Enhanced collagenase activity in diabetic rat gingiva: in vitro and in vivo evidence. J Dent Res 57: 520-525

16. Haft DE, Reddi AS (1979) Glucosyltransferase activity in kidney fractions of normal and streptozotocin diabetic rats. Biochim Biophys Acta 584: 1-10

17. Hoftiezer V, Carpenter AM (1973) Comparison of streptozotocin and alloxan-induced diabetes in the rat, including volumetric quantitation of the pancreatic islets. Diabetologia 9: 178-184

18. Kawai $Y$, Anno K (1971) Mucopolysaccharide degrading enzymes from the liver of the squid, ommastrephes sloani pacificus I hyaluronidase. Biochim Biophys Acta 242: 428-436

19. Lowry OH, Rosebrough NJ, Farr AL, Randall RJ (1951) Protein measurement with the folin phenol reagent. J Biol Chem 193: 265-275

20. Mahadevan S, Dillard CJ, Tappel AL (1969) Degradation of polysaccharides mucopolysaccharides and glycoproteins by lysosomal glycosidases. Arch Biochem Biophys 129: 525-533

21. Mahadevan S, Tappel AL (1968) Subcellular distribution of O-seryl-N-acetylgalactosaminide glycosidase in rat liver and kidney. Arch Biochem Biophys 128: 129-132

22. Mansford KRL, Opie L (1968) Comparison of metabolic abnormalities in diabetes mellitus induced by streptozotocin or by alloxan. Lancet 1: 670-671

23. Merimee TJ, Kennedy AL, Mehl TD, Rosenbloom A (1981) Serum glycosidase activity in diabetes mellitus. Diabetes 30 : $115-118$

24. Mohanam S, Bose SM (1981) Influence of streptozotocin and alloxan induced diabetes on the metabolism of dermal collagen in albino rats. Acta Diabetol Lat 18: 251-258

25. Mohanam S, Bose SM (1982) Influence of streptozotocin and alloxan induced diabetes on the crosslinking of dermal collagen. Acta Diabetol Lat 19:211-218

26. Morrison RIG, Barrett AJ, Dingle JT, Prior D (1973) Cathepsin $B_{1}$ and $\mathrm{D}$, action on human cartilage proteoglycans. Biochim Biophys Acta 302: $411-419$

27. Nakagawa H, Aihara K, Tsurfuji S (1977) The role of cathepsin $B_{1}$ in the collagen breakdown of carrageenin granuloma in rats. J Biochem (Tokyo) 81: 801-804

28. Niebes F, Ponard G (1975) Stabilization of rat liver lysosomes by (士) cyanidan-3-ol in vivo. Biochem Pharmacol 24:905-909 
29. Ramamurthy NS, Zebrowski EJ, Golub LM (1973) Collagenolytic activity of gingivae from alloxan diabetic rats. Diabetes 22: 272-274

30. Rosenbilt PD, Metzger RP, Wick AN (1974) Effect of streptozotocin diabetes on acid phosphatase and selected glycosidase activities of serum and various rat organs. Proc Soc Exp Biol Med 145: 244-248

31. Sapolsky AI, Altman RD, Howell DS (1973) Cathepsin D activity in normal and osteoarthritic human cartilage. Fed Proc 32: 1489-1493

32. Silberberg R, Hirshberg GE, Lesker PA (1977) Enzyme studies in the articular cartilage of diabetic rats and of rats bearing transplanted pancreatic islets. Diabetes 26: 732-735

33. Tarui S, Saito Y, Fushimi H (1976) The progression of diabetic microangiopathy and lysosomal glycosidases: clinical studies in Japanese diabetics and experimental approaches with the streptozotocin-diabetic rats. In: Bata S, Goto Y, Fukui I (eds) Diabetes mellitus in Asia. Ecological aspects of epidemiology, complications and treatment. Excerpta Medica, Amsterdam, pp 212-221

34. Terato K, Nagai Y, Kawanishi K, Yamamoto S (1976) A rapid assay method of collagenase activity using ${ }^{14} \mathrm{C}$-labelled soluble collagen as substrate. Biochim Biophys Acta 445: 753-762
35. Tulsiani DRP, Buschiazzo HO, Tolbert B, Touster O (1977) Changes in plasma hydrolase activities in hereditary and streptozotocin induced diabetes. Arch Biochem Biophys 181:216-227

36. Veleminsky J, Burr IM, Stauffacher W (1970) Comparative study of early metabolic events resulting from the administration of the two diabetogenic agents alloxan and streptozotocin. Eur J Clin Invest 1: 104-108.33

37. Woessner JF Jr (1962) Catabolism of collagen and non-collagen protein in the rat uterus during post partum involution. Biochem $\mathrm{J}$ 83: 304-314

38. Wolinsky H, Goldfischer S, Capron L, Capron F, Coltoff-Schiller B, Kasak L (1978) Hydrolase activities in the rat aorta I Effects of diabetes mellitus and insulin treatment. Circ Res 42: 821-831

Received: 15 June 1982

and in revised form: 18 May 1983

S. Mohanam

Biochemistry Laboratory

Central Leather Research Institute

Adyar, Madras 600020

India 